\title{
Study on the Surface Quality Defects and Repair Measures of Composite Wallboard after Stripping
}

\author{
Chunyi $\mathrm{Xu}^{1, \mathrm{a}^{*}}$,Shengdong $\mathrm{Li}^{1, \mathrm{~b}}$, Chunlei $\mathrm{Xu} \mathrm{u}^{2, \mathrm{~d}}$ and Hui Cao ${ }^{1, \mathrm{c}}$ \\ ${ }^{1}$ School of Civil Engineering, Shenyang Jianzhu University, Shenyang 110168, China \\ ${ }^{2}$ Tieling municipal commission of housing and urban-rural development, Tieling 112000, China \\ a1174088424@qq.com, b1696334481@qq.com, ${ }^{\text {c} 530997841 @ q q . c o m, ~ d 117132079 @ q q . c o m ~}$
}

Keywords: defect inspecti; wallboard classification; member repaired measure

Abstract.Composite wallboard will arise various problems of its surface quality which will affect $t$ he appearance as well as the durability of the composite wallboard if they are slight and influence $t$ he using function otherwise. This article mainly conducts systematically about the quality defects, $g$ et through the inspection and swash of the composite wallboard after demolding as well as come up with standard, viable and complementary project about the members that can be repaired accordin $\mathrm{g}$ to the results of the inspection.

\section{Introduction}

Composite wall is compounded by a variety of building materials, which replace the traditional brick with a shorter duration, Insulation light weight composite wall structure system, excellent thermal and noise insulation[1,2] ,but the composite panels are not being taken seriously in the production and the release process, it will cause damage to components which can not be used because of improper way of production and releasing, paper focuses on composite wall after release into the mass defect inspection, then put forward credible remedial measures.

\section{Composite wall after stripping inspection and flus hing}

After releasing the lifting member to the flushing area, there will be a visual inspection, including wall flatness, dimensions, exposed steel length, quality and other connector installation. According to test results processed as follows:

All of the qualified wallboard will be sent to storage areas after rinse and marked, As shown in Figure 1.

For defective wallboard which has the appearance of bubbles, cracks or does not affect the structure of the crack, some shortcomings of flatness error or dimension wallboard will be washed first then repaired.

For serious flawed composite wall :damage affect the structural properties and can not be restored; wallboard damage which affect the reinforced, sleeve and anchors embedded parts, cracks affect the structural properties of nonrecoverable, reinforcing steel, fittings, crack embedded anchoring and crack width is greater than $0.3 \mathrm{~mm}$, and the crack length exceed $300 \mathrm{~mm}$ of wall cracks, do scrap. According to the above composite wall inspection results may be divided into: surface quality is defective component defect, according to the extent of the damage in two stages, the general level of defects can be repaired, two serious defects, scrap.

\section{Compound wall surface quality defects and reasons}

Based on the investigation and findings found that the surface quality defects in composite panels are prone to: cellular, pockmarked face, exposed tendons, cracks, missing edge off angle.

Honeycomb. Cellular concrete structure refers to the emergence of local crisp, less mortar, stones and more similar to a honeycomb hole formation of voids between the stones. The main reason forms cellular include: Mix properly, much less pulp stone; concrete mixing time is not enough, which 
leads to separation of mortar and stones, or vibrated not dense, causing segregation; mold does not close the gap, resulting in excessive loss of water, mud and so on[3].

Exposed tendons. Exposed tendons refers to reinforced concrete exposed surface of the member of a local phenomenon. The reason for this phenomenon includes: pouring reinforced concrete pad protective layer is too small quantity, cement mortar can not be filled steel cause exposed tendons; concrete cover is too small, no real protection at the vibrators, vibrators impact or personnel stampede steel cage, make steel shift causing exposed tendons.

Crack. Precast concrete cracks often appear with a temperature stress cracks, plastic shrinkage cracks, stress cracks embedded parts holes at late surface cracking.

Temperature stress crack formation at high temperature to low temperature steam curing convergence stage, when the stripping, member by the outside temperature influence, cooling shrinkage of concrete, concrete thermal cond uctivity due to the poor, within and outside the concrete cooling rate is inconsistent, the degree of contraction also will be different inside and outside. Such differences make concrete inside and outside surfaces of contraction to be bound inside the concrete and will have a large tensile stress, from the raw stress[4].

Plastic shrinkage cracks usually appear in the component placement surface (table wiping plane), because it is concrete in a plastic stage excessive evaporation surface cracks produced, therefore we are before the release can be found, and with the gradual hardening of members and wider, growth, crack width up to $0.5-1.0 \mathrm{~mm}$, depth of up to $1.0-1.5 \mathrm{~mm}[5]$.

Embedded parts where stress concentration, a greater constraint on the concrete stress, and the thermal expansion coefficient of concrete with embedded parts have a certain margin, when such binding and temperature stress is greater than the concrete tensile stress, will be in the pre-buried member surrounding a stress fracture, as shown in Figure 2.

The missing edge off angle. Missing ed ge off angle is the missing edge off angle phenomenon refers to the structure or members of local falling concrete corners, irregular, angular defects. The causes are: Form removal violently, resulting in prefabricated corners are knocked; form removal is not properly protected, so that member edges and damage by external force or with heavy impact[6], As shown in Figure 3.

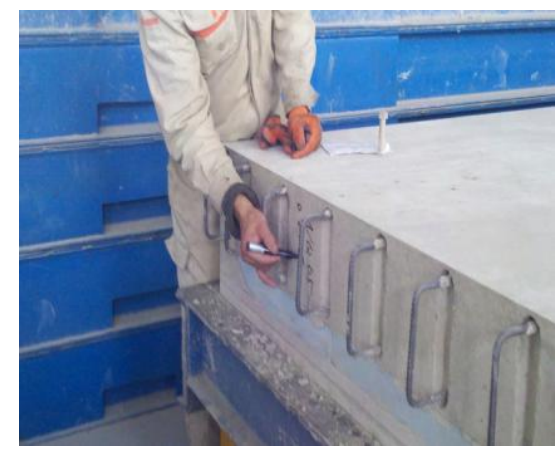

Fig. 1 Temporary mark. Fig.

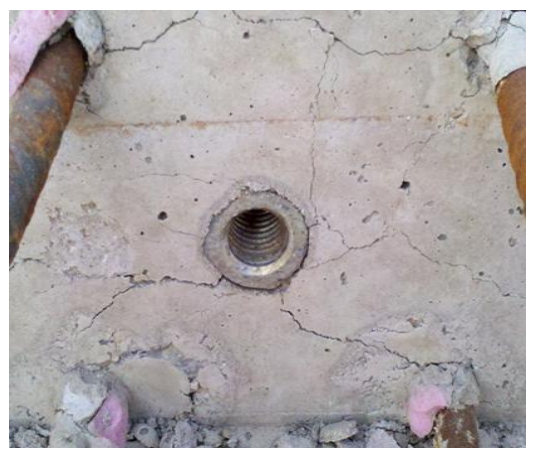

2 Stress crack Fig.

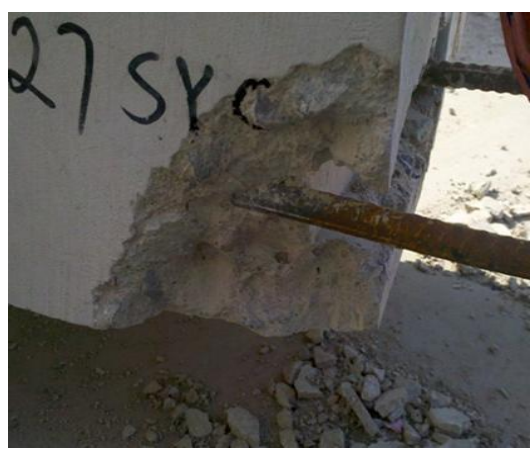

$3 \mathrm{M}$ is sing edge off angle

\section{Remedial measures}

Depending on the severity of which reject its surface quality defects can be divided into primary defects (defects in general, can be repaired) and secondary defects (serious defects, scrap). Table 1 is a composite wall surface damage and treatment program. 
Table 1 Composite wallboard surface damage and treatment scheme

\begin{tabular}{|c|c|c|c|c|}
\hline Name & \multicolumn{2}{|c|}{$\begin{array}{l}\text { General defects and remedial } \\
\text { measures }\end{array}$} & \multicolumn{2}{|c|}{ Serious defects and treatment measures } \\
\hline $\begin{array}{l}\text { Surface } \\
\text { quality } \\
\text { defects }\end{array}$ & A defective & $\begin{array}{l}\text { Remedial } \\
\text { measures }\end{array}$ & Two defective & Actions \\
\hline Honeycomb & $\begin{array}{l}\text { Unstressed parts of } \\
\text { a cell that affects } \\
\text { the appearance and } \\
\text { durability of the } \\
\text { components. }\end{array}$ & Patch 1 & $\begin{array}{l}\text { Main of a large area of } \\
\text { cellular and structural } \\
\text { performance of } \\
\text { components affected. }\end{array}$ & \multirow{4}{*}{ Scrap } \\
\hline $\begin{array}{l}\text { Exposed } \\
\text { tendons }\end{array}$ & $\begin{array}{c}\text { A small area of } \\
\text { exposed tendons, } \\
\text { does not affect the } \\
\text { structural } \\
\text { performance, } \\
\text { affect the } \\
\text { appearance. }\end{array}$ & Patch 2 & $\begin{array}{c}\text { The reinforced exposed } \\
\text { beyond } 500 \mathrm{~mm} \text {, affect } \\
\text { the structural properties } \\
\text { of components. }\end{array}$ & \\
\hline Crack & $\begin{array}{l}\text { A few do not affect } \\
\text { the structural } \\
\text { performance or } \\
\text { functionality of } \\
\text { cracks, but affect } \\
\text { the appearance. }\end{array}$ & Patch 3 & $\begin{array}{l}\text { Crack width is greater } \\
\text { than } 0.3 \mathrm{~m} \text { and crack } \\
\text { length exceed s } \\
0.3 \mathrm{~m} \text {;reinforcing steel, } \\
\text { the impact of structural } \\
\text { performance }\end{array}$ & \\
\hline $\begin{array}{l}\text { Missing edge } \\
\text { off angle }\end{array}$ & $\begin{array}{l}\text { The use of the } \\
\text { function and } \\
\text { influence the } \\
\text { perception of } \\
\text { quality defects, to } \\
\text { be repaired. }\end{array}$ & Patch4 & $\begin{array}{l}\text { There are serious } \\
\text { implications for the use } \\
\text { of the function and } \\
\text { appearance quality } \\
\text { defects }\end{array}$ & \\
\hline
\end{tabular}

Note: Patch 1: small cell, after washing with 1: 2.5 cement mortar smooth compaction; larger cellular, cellular weak part required tools chisel away with trowe1 1:2 cement mortar strong pressure and evenness within the cell[7].

Patch 2: If the member surface exposed tendons, with $1: 2$ or $1: 2.5$ cement mortar will be exposed tendons site wiping pressure level, and conservation; if exposed tendons deeper, to chisel away the weak concrete and rinse, then than the original high-level fine aggregate concrete filling voids, compacted and conservation.

Patch 3: cracks should select the appropriate processing method according to the degree of serious and harmful: little effect on the structural

strength of a width of less than $0.2 \mathrm{~mm}$, can be used for waterproofing repair, but when the crack width of more than $0.2 \mathrm{~mm}$, cracks need to be closed slurry coated with epoxy resin processing.

Patch 4: for relatively small angular missing edge off angle phenomenon, if you do not affect the overall quality and appearance requirements, can not handle; prefabricated angular rupture, rinse with water after taking partial formwork, use of prefabricated units higher than the original a grade of cement formulation 1:2 or 1: 2.5 cement mortar repair, wiping solid form flattened corners, and conservation. 


\section{Conclusion}

The severity of the composite wall defect inspection, and based on the component defect classification process, the surface quality of a defective component deemed defective, and the extent of damage will be divided into two, one for the general defects, can be repaired, two serious flaws, do scrap processing, all qualified members direct flushing, after hoisting the storage area.

Acknowledgement

Natural Science Foundation Project(grant number: 51408373) and Liaoning Province Education Department Project(grant number : L2013231).

\section{References}

[1] Summary of research [D]. Assembling energy-saving composite wall performance. Central South University, 2014,1-2.

[2] CaoHui, ChenFengChuang research precast concrete sandwich panels production process [C]. Civil Engineering Construction Management, 2012 (7), 102-107.

[3] Long chant. Causes and Prevention of reinforced concrete Common Quality Diseases [J]. Sichuan building materials, 2010,65-66.

[4]Sidney Ming, Yang Wei, Francis, Darwin. A concrete [M].Beijing: Chemical Industry Press, 2005

[5] Liang Guancheng formation of cracks in the concrete precast production cycle and Prevention [D]. South China University of Technology, 2009,8-10

[6] is loose, Fan Guangyu. Measures of Quality Control for the concrete [J]. Technology \& Economy. 2006,45-46

[7] Yu Tao, Otto Lin Xing, Wang Xuehua. The apparent high quality precast concrete pile wharf control [J]. China Water Transport, 2012,12 (9): 117-120 